\title{
FEATURES OF DENTINE CHEMICAL COMPOSITION OF INTACT TEETH AND TEETH WITH WEDGE-SHAPED DEFECTS
}

DOI: 10.36740/WLek202108116

\author{
Svitlana P. Yarova, Iryna I. Zabolotna, Olena S. Genzytska, Andrii A. Komlev \\ DONETSK NATIONAL MEDICAL UNIVERSITY, LYMAN, UKRAINE
}

\begin{abstract}
The aim: Is to define dentine chemical composition of intact teeth and those with wedge-shaped defects followed by the analysis of revealed differences.

Materials and methods: Longitudinal sections of 22 clinically removed teeth (12 - clinically intact ones, 10 - with wedge-shaped defects) from both jaws were studied in patients aged between 25-54 years. JSM-6490 LV focused beam electron microscope (scanning) with system of energy-dispersive X-ray microanalysis INCA Penta FETx3 was used. The chemical composition of 148 dentine areas in the incisal region (tubercle), equator, cervical area has been determined as a percentage of the weight amounts of carbon, oxygen, calcium, phosphorus, sodium, magnesium, sulfur, chlorine, zinc, potassium, aluminum.

Results: Dentine chemical composition of teeth with wedge-shaped defects differed from those of intact teeth by significantly lower content: sodium, chlorine and calcium in the incisal region (tubercle); sodium, magnesium - at the equator; sodium, chlorine and calcium - in the cervical region ( $p \leq 0.05$ ). In the sample groups with cervical pathology there was more sulfur and oxygen in the incisal region (tubercle), phosphorus and zinc - at the equator, carbon and potassium - in the cervical region ( $\mathrm{p} \leq 0.05$ ). Conclusions: Differences in the chemical composition of intact teeth and teeth with wedge-shaped defects, the presence of correlation between the studied chemical elements confirm the role of macro- and microelements in the pathogenesis of non-carious cervical lesions.
\end{abstract}

KEY WORDS: tooth wear, dentine, non-carious cervical lesions, scanning electron microscope

Wiad Lek. 2021;74(8):1869-1875

\section{INTRODUCTION}

Epidemiological studies of non-carious cervical lesions (NCCL) are carried out in all regions of the world that is fully justified by their high prevalence $(36.8 \%$ [1], $52 \%$ [2], 67.8\% [3], 68.5\% [4], 88.1\% [5]) and possible consequences [4]. The results of such studies are very important for identifying new etiological factors taking into account the patient's individual characteristics that are responsible for different degrees of the loss of dental hard tissue and the development of combined forms of damage $[4,6]$. The progression of this pathology negatively affects the tooth structural integrity [6], pulp viability $[6,7]$ and it also leads to aesthetic problems $[2,6,7]$, dental plaque retention $[6$, 7], the development of hyperesthesia [5-7].

The most likely causes of NCCL development are abrasion (61.60\%), erosion (26.08\%), abfraction (12.32\%) [1] or any combination of them $[2,6]$. The frequency of this pathology increases with age [3-6] and the number of retained teeth [6] that indicates the long-term component in their formation associated with occlusive stress $[1,3$, 5] which initially develops in enamel cracks $[6,7]$. The presence of microcracks leads to disruption of chemical bonds between hydroxyappatite crystals, subsequent penetration of water and other molecules making a tooth more vulnerable to dissolution, chemical erosion or abrasive factors [7]. It is the cervical region where there are wedge-shaped defects with sharp angles converging in the region where the greatest loading is generated $[6,8]$. According to the findings significant occlusal force on teeth is diagnosed by the presence of wear facets that were determined in $78 \%$ of examined patients with NCCL [7]. The presence of occlusal wear facets and microcracks in teeth with wedge-shaped defects confirms occlusal stress as the main etiological factor, and in some cases it's the root cause of the development of this NCCL form [7]. It is known from the literature review [6] that not all clinical studies show a positive correlation between occlusal loading and abfraction lesions. Probably, occlusal loading is a part of a multifactorial phenomenon that does not necessarily follow from the assumed classical mechanism of abfraction [6].

Nowadays the clinical picture of wedge-shaped defects is described, histological [9] and morphological $[8,10,11]$ features of their structure are determined. But insufficient attention is paid to the mineral composition of teeth with NCCL, although a number of researchers confirm the link of the morphological structure with the number of chemical elements and the features of the manifestation of the pathology of hard tissues of both carious and non-carious origin $[11,12]$. The absence of certain minerals can affect the content of other minerals and lead to greater vulnerability of teeth to pathological processes [13]. Since the prevalence of NCCL tends to increase [7] it is important for clinicians to recognize etiological factors and their combination [5], identify the patterns of the processes as- 
sociated with the chemical structure of enamel and dentin $[11,12]$. Therefore, the comparative analysis of the content of macro- and microelements in the dentin of intact teeth and teeth with wedge-shaped defects seems completely justified and necessary.

\section{THE AIM}

To determine dentin chemical composition of intact teeth and teeth with wedge-shaped defects with subsequent analysis of the revealed differences.

\section{MATERIALS AND METHODS}

Longitudinal sections of 22 clinically removed teeth of both jaws (12 clinically intact ones, 10 with wedge-shaped defects) were studied in patients aged 25-54. The teeth were extracted for orthodontic indications. The samples were washed under running water, purified from blood clots and stored in formalin. To make the sections the teeth were cut along the central axis through the middle part of the vestibular surface using diamond discs, then they were put in molds and filled with quick-hardening resins. The samples were ground and polished after polymerization [14]. We used JSM-6490 LV focused beam electron microscope (scanning) with system of energy-dispersive X-ray microanalysis INCA Penta FETx3 (OXFORD Instruments, England). The sections were fixed on a glass slide and they were filled with carbon in the vacuum device. To perform quantitative $\mathrm{X}$-ray spectral microanalysis standard samples were used. We calculated local mass fractions of chemical elements using the picfon ratio method taking into account the corrections for atomic number, fluorescence and absorption, measured in normal mass percentage (normal mass \%). The mineral composition of 148 dentin areas in the incisal region (tubercle), equator, cervical area has been determined as a percentage of the weight amounts of carbon, oxygen, calcium, phosphorus, sodium, magnesium, sulfur, chlorine, zinc, potassium, and aluminum. Replication measurements were averaged in one sample before statistical analysis. The study was conducted at the base of Donetsk Institute of Physics and Technology of the National Academy of Sciences of Ukraine. The work was performed in accordance with the principles of WMA Declaration of Helsinki "Ethical Principles for Medical Research involving Human Subjects", Order No. 690 of the Ministry of Health of Ukraine (dated September 23, 2009) and approved by Bioethics Commission of Donetsk National Medical University. Before being involved in the survey all the participants were provided with written informed consent.

The degree of reliability of the results was ensured by the use of certified equipment, correctness of the statistical processing of obtained findings. The analysis of variance was performed using Kruskal-Wallis test and according to the test the differences in the content of chemical elements in dentin were revealed. The differences at $p \leq 0.05$ were considered statistically significant. In order to evaluate the relationship between the variables the correlation analysis (Pearson's parametric correlation method) was performed with the confidence level of $95 \%$. The statistical processing was performed using the computer program Statistica 8.0 (STA862D175437Q).

\section{RESULTS}

The analysis of the chemical composition of the surface enamel of teeth with wedge-shaped defect was presented in previously published papers. Depending on the depth of microcracks a significant difference in the quantitative distribution of phosphorus areas was determined in the examined enamel, $\mathrm{p} \leq 0.05$ [15]. While studying dental dentin with NCCL the link between the content of magnesium and calcium and the depth of defects of the vestibular enamel surface $(p \leq 0.05)$ has been determined [14]. The comparative analysis of the number of macro- and microelements in teeth with wedge-shaped defects and clinically intact teeth has been carried out to confirm the assumption of differences in dentin chemical composition depending on the state of hard tissues. The obtained results of the samples from the area of the incisal region (tubercle) are presented in table I.

The differences in the content of sodium, chlorine, and calcium were revealed: their concentration was significantly lower in the group of the samples with NCCL compared to intact ones $(\mathrm{p} \leq 0.05)$. There was more sulfur and oxygen in the dentin of teeth with wedge-shaped defects $(p \leq 0.05)$.

Examined parts of dentin in the area of the incisal region (tubercle) are presented in figure 1.

The results of the revealed correlation between the chemical elements of high strength in the area of the incisal region (tubercle) are shown in Table II.

An indirect correlation has been determined in the group of the samples with NCCL between carbon and calcium, carbon and phosphorus, a direct one - between phosphorus and calcium $p<0.001$. An indirect correlation was observed in clinically intact teeth between the content of carbon and calcium, carbon and oxygen, carbon and sodium, calcium and zinc; a direct correlation between sodium and magnesium, sodium and calcium, calcium and oxygen, calcium and magnesium, $\mathrm{p} \leq 0.001$.

Examined parts of dentin in the area of the equator are presented in figure 2 .

The differences in the amount of sodium, magnesium, phosphorus and zinc have been revealed in dentin chemical composition in the equator area depending on the state of dental hard tissues $(\mathrm{p} \leq 0.05)$ (table III).

The content of sodium and magnesium was significantly high in intact samples $(0.80 \pm 0.21$ normal mass $\%$ and $0.58 \pm 0.08$ normal mass $\%$, respectively), $p \leq 0.05$. The concentration of phosphorus and zinc was statistically significantly higher in teeth with wedge-shaped defects $(12.87 \pm$ 0.53 normal mass $\%$ and $0.21 \pm 0.49$, respectively), $\mathrm{p} \leq 0.05$.

The results of the revealed correlation between the chemical elements of high strength in the area of the equator are shown in Table IV. 
Table I. The chemical composition of dentin incisal region (tubercle)

\begin{tabular}{|c|c|c|c|}
\hline $\begin{array}{l}\text { Chemical element } \\
\text { (normal mass \%) }\end{array}$ & $\begin{array}{l}\text { Teeth with wedge-shaped defects } \\
\qquad \begin{array}{l}(\bar{X} \pm m) \\
(n=21)\end{array}\end{array}$ & $\begin{array}{l}\text { Clinically intact teeth } \\
\qquad \begin{array}{l}(\bar{X} \pm m) \\
(n=20)\end{array}\end{array}$ & $\mathbf{P}$ \\
\hline $\mathrm{C}$ & $27.52 \pm 1.57$ & $26.97 \pm 3.69$ & 0.110 \\
\hline $\mathrm{O}$ & $36.54 \pm 0.67$ & $35.81 \pm 1.89$ & $0.050^{*}$ \\
\hline $\mathrm{Na}$ & $0.36 \pm 0.06$ & $0.77 \pm 0.25$ & $<0.001^{*}$ \\
\hline $\mathrm{Mg}$ & $0.44 \pm 0.08$ & $0.41 \pm 0.16$ & 0.580 \\
\hline $\mathrm{Al}$ & $0.02 \pm 0.02$ & $0.02 \pm 0.04$ & 0.310 \\
\hline $\mathrm{P}$ & $12.46 \pm 0,54$ & $12.21 \pm 0.28$ & 0.060 \\
\hline$S$ & $0.10 \pm 0.05$ & $0.07 \pm 0.03$ & $0.030^{*}$ \\
\hline $\mathrm{Cl}$ & $0.09 \pm 0.04$ & $0.14 \pm 0.05$ & $0.001^{*}$ \\
\hline K & $0.02 \pm 0.02$ & $0.04 \pm 0.04$ & 0.070 \\
\hline $\mathrm{Ca}$ & $22.46 \pm 1.07$ & $23.61 \pm 1.78$ & $0.004^{*}$ \\
\hline $\mathrm{Zn}$ & $0.05 \pm 0.06$ & $0.05 \pm 0.07$ & 0.350 \\
\hline
\end{tabular}

Note: $\mathrm{P}$ - the statistical significance of differences; $\mathrm{n}$ - number of dentine areas; ${ }^{*}$ the difference between the groups is statistically significant, $\mathrm{p} \leq 0.05$

Table II. Correlation between the content of the chemical elements in dentin of the incisal region (tubercle), $r$

\begin{tabular}{|c|c|c|c|c|c|c|c|}
\hline \multirow{2}{*}{$\begin{array}{l}\text { Chemical } \\
\text { element }\end{array}$} & \multicolumn{2}{|c|}{$\begin{array}{l}\text { Teeth with wedge-shaped defects } \\
\qquad(\mathrm{n}=21)\end{array}$} & \multicolumn{5}{|c|}{$\begin{array}{l}\text { Clinically intact teeth } \\
\qquad(n=20)\end{array}$} \\
\hline & C & $\mathrm{Ca}$ & C & $Z_{n}$ & 0 & $\mathrm{Na}$ & $\mathrm{Ca}$ \\
\hline $\mathrm{Ca}$ & $\begin{array}{c}-0.902 \\
p<0.001\end{array}$ & & $\begin{array}{c}-0.938 \\
p<0.001\end{array}$ & $\begin{array}{c}-0.670 \\
p=0.001\end{array}$ & $\begin{array}{c}0.706 \\
p<0.001\end{array}$ & $\begin{array}{c}0.809 \\
p<0.001\end{array}$ & \\
\hline$P$ & $\begin{array}{c}-0.856 \\
p<0.001\end{array}$ & $\begin{array}{c}0.938 \\
p<0.001\end{array}$ & & & & & \\
\hline O & & & $\begin{array}{l}-0.902 \\
p<0.001\end{array}$ & & & & $\begin{array}{c}0.706 \\
p<0.001\end{array}$ \\
\hline $\mathrm{Na}$ & & & $\begin{array}{c}-0.712 \\
p<0.001\end{array}$ & & & & \\
\hline $\mathrm{Mg}$ & & & & & & $\begin{array}{c}0.738 \\
p<0.001\end{array}$ & $\begin{array}{c}0.694 \\
p<0.001\end{array}$ \\
\hline
\end{tabular}

Note: $p$ - the statistical significance of differences; $r$ - Pearson correlation coefficient

Table III. The chemical composition of dentin equator

\begin{tabular}{|c|c|c|c|}
\hline $\begin{array}{l}\text { Chemical element } \\
\text { (normal mass \%) }\end{array}$ & $\begin{array}{l}\text { Teeth with wedge-shaped defects } \\
\qquad \begin{array}{l}(\bar{X} \pm m) \\
(n=26)\end{array}\end{array}$ & $\begin{array}{l}\text { Clinically intact teeth } \\
\qquad \begin{array}{l}(\bar{X} \pm m) \\
(n=26)\end{array}\end{array}$ & $\mathbf{P}$ \\
\hline $\mathrm{C}$ & $23.37 \pm 3.68$ & $24.45 \pm 3.16$ & 0.340 \\
\hline $\mathrm{O}$ & $36.68 \pm 1.61$ & $37.00 \pm 2.33$ & 0.960 \\
\hline $\mathrm{Na}$ & $0.67 \pm 0.46$ & $0.80 \pm 0.21$ & $0.030^{*}$ \\
\hline $\mathrm{Mg}$ & $0.33 \pm 0.09$ & $0.58 \pm 0.08$ & $<0.001^{*}$ \\
\hline $\mathrm{Al}$ & $0.04 \pm 0.05$ & $0.04 \pm 0.05$ & 0.910 \\
\hline$P$ & $12.87 \pm 0.53$ & $12.02 \pm 0.32$ & $<0.001^{*}$ \\
\hline$S$ & $0.11 \pm 0.08$ & $0.08 \pm 0.04$ & 0.310 \\
\hline $\mathrm{Cl}$ & $0.13 \pm 0.11$ & $0.11+0.09$ & 0.750 \\
\hline $\mathrm{K}$ & $0.04 \pm 0.04$ & $0.02 \pm 0.02$ & 0.110 \\
\hline $\mathrm{Ca}$ & $25.65 \pm 2.22$ & $24.91 \pm 1.02$ & 0.240 \\
\hline $\mathrm{Zn}$ & $0.21 \pm 0.49$ & $0.06 \pm 0.11$ & $0.040^{*}$ \\
\hline
\end{tabular}

Note: $\mathrm{P}$ - the statistical significance of differences; $\mathrm{n}$ number of dentine areas; ${ }^{*}$ the difference between the groups is statistically significant, $\mathrm{p} \leq 0.05$. 
Table IV. Correlation between the content of the chemical elements in dentin of the equator, $r$

\begin{tabular}{|c|c|c|c|c|c|c|c|}
\hline \multirow{2}{*}{$\begin{array}{l}\text { Chemical } \\
\text { element }\end{array}$} & \multicolumn{5}{|c|}{$\begin{array}{l}\text { Teeth with wedge-shaped defects } \\
\qquad(\mathrm{n}=26)\end{array}$} & \multicolumn{2}{|c|}{$\begin{array}{l}\text { Clinically intact teeth } \\
\qquad(n=26)\end{array}$} \\
\hline & C & $\mathrm{Ca}$ & $\mathrm{Zn}$ & 0 & $\mathrm{Na}$ & C & $\mathrm{Ca}$ \\
\hline $\mathrm{Ca}$ & $\begin{array}{l}-0.963 \\
p<0.001\end{array}$ & & & $\begin{array}{c}0.719 \\
p<0.001\end{array}$ & & $\begin{array}{l}-0.903 \\
p<0.001\end{array}$ & \\
\hline$P$ & $\begin{array}{l}-0.654 \\
p<0.001\end{array}$ & & $\begin{array}{l}-0.699 \\
p<0.001\end{array}$ & $\begin{array}{c}0.667 \\
p<0.001\end{array}$ & & & $\begin{array}{c}0.704 \\
p=0.002\end{array}$ \\
\hline 0 & $\begin{array}{c}-0.834 \\
p<0.001\end{array}$ & $\begin{array}{c}0.719 \\
p<0.001\end{array}$ & $\begin{array}{c}-0.707 \\
p<0.001\end{array}$ & & & $\begin{array}{c}-0.958 \\
p<0.001\end{array}$ & $\begin{array}{c}0.765 \\
p<0.001\end{array}$ \\
\hline $\mathrm{Mg}$ & & & & $\begin{array}{c}0.716 \\
p<0.001\end{array}$ & & & \\
\hline $\mathrm{Cl}$ & & & $\begin{array}{c}0.768 \\
p<0.001\end{array}$ & & $\begin{array}{c}0.712 \\
p<0.001\end{array}$ & & \\
\hline $\mathrm{Zn}$ & & & & $\begin{array}{c}-0.707 \\
p<0.001\end{array}$ & $\begin{array}{c}0.692 \\
p<0.001\end{array}$ & & \\
\hline
\end{tabular}

Note: $p$ - the statistical significance of differences; $r$ - Pearson correlation coefficient

Table V. Chemical composition of cervical dentin

\begin{tabular}{cccc}
\hline $\begin{array}{c}\text { Chemical element } \\
\text { (normal mass \%) }\end{array}$ & $\begin{array}{c}\text { Teeth with wedge-shaped defects } \\
(\overline{\mathrm{X}} \pm \mathbf{m}) \\
(\mathbf{n}=\mathbf{2 6})\end{array}$ & $\begin{array}{c}\text { Clinically intact teeth } \\
(\overline{\mathrm{X}} \pm \mathbf{m}) \\
(\mathbf{n}=\mathbf{2 9 )}\end{array}$ & $\mathbf{P}$ \\
\hline $\mathrm{C}$ & $26.59 \pm 2.67$ & $23.05 \pm 3.12$ & $0.001^{*}$ \\
\hline $\mathrm{O}$ & $39.12 \pm 4.81$ & $36.75 \pm 3.26$ & 0.580 \\
\hline $\mathrm{Na}$ & $0.42 \pm 0.14$ & $1.01 \pm 0.41$ & $<0.001^{*}$ \\
\hline $\mathrm{Mg}$ & $0.29 \pm 0.13$ & $0.34 \pm 0.20$ & 0.540 \\
\hline $\mathrm{Al}$ & $0.03 \pm 0.03$ & $0.02 \pm 0.03$ & 0.540 \\
\hline $\mathrm{P}$ & $11.86 \pm 1.53$ & $12.27 \pm 0.45$ & 0.310 \\
\hline $\mathrm{S}$ & $0.10 \pm 0.06$ & $0.08 \pm 0.06$ & 0.180 \\
\hline $\mathrm{Cl}$ & $0.12 \pm 0.06$ & $0.23 \pm 0.12$ & $<0.001^{*}$ \\
\hline $\mathrm{K}$ & $0.03 \pm 0.04$ & $0.01 \pm 0.01$ & $0.030^{*}$ \\
\hline $\mathrm{Ca}$ & $21.39 \pm 3.96$ & $25.27 \pm 1.33$ & $<0.001^{*}$ \\
\hline $\mathrm{Zn}$ & $0.09 \pm 0.11$ & $0.10 \pm 0,10$ & 0.620
\end{tabular}

Note: $P$ - the statistical significance of differences; $n$ number of dentine areas; ${ }^{*}$ the difference between the groups is statistically significant, $p \leq 0.05$.

Table VI. Correlation between the content of the chemical elements of the cervical dentin, $r$

\begin{tabular}{|c|c|c|c|c|c|c|c|}
\hline \multirow{2}{*}{$\begin{array}{l}\text { Chemical } \\
\text { element }\end{array}$} & \multicolumn{2}{|c|}{$\begin{array}{l}\text { Teeth with wedge-shaped defects } \\
\qquad(n=26)\end{array}$} & \multicolumn{5}{|c|}{$\begin{array}{l}\text { Clinically intact teeth } \\
(n=29)\end{array}$} \\
\hline & $\mathrm{Ca}$ & $\mathbf{P}$ & 0 & $\mathbf{P}$ & C & $\mathrm{Na}$ & $\mathrm{Ca}$ \\
\hline $\mathrm{Ca}$ & & $\begin{array}{c}0.905 \\
p<0.001\end{array}$ & & & $\begin{array}{l}-0.917 \\
p<0.001\end{array}$ & $\begin{array}{l}-0.757 \\
p=0.001\end{array}$ & \\
\hline$P$ & $\begin{array}{c}0.905 \\
p<0.001\end{array}$ & & & & $\begin{array}{l}-0.875 \\
p<0.001\end{array}$ & & $\begin{array}{c}0.810 \\
p<0.001\end{array}$ \\
\hline 0 & $\begin{array}{c}-0.889 \\
p<0.001\end{array}$ & $\begin{array}{c}-0.804 \\
\mathrm{p}<0.001\end{array}$ & & $\begin{array}{c}0.674 \\
p=0.004\end{array}$ & $\begin{array}{c}-0.893 \\
p<0.001\end{array}$ & $\begin{array}{c}-0.846 \\
p<0.001\end{array}$ & $\begin{array}{c}0.931 \\
p<0.001\end{array}$ \\
\hline $\mathrm{Cl}$ & & & $\begin{array}{l}-0.867 \\
p<0.001\end{array}$ & & $\begin{array}{c}0.812 \\
p<0.001\end{array}$ & $\begin{array}{c}0.736 \\
p=0.001\end{array}$ & $\begin{array}{l}-0.803 \\
p=0.001\end{array}$ \\
\hline
\end{tabular}

Note: $p$ - the statistical significance of differences; $r$ - Pearson correlation coefficient

The correlation analysis revealed an indirect correlation in both groups: between carbon and oxygen content; carbon and calcium, a direct correlation - between calcium and oxygen, $\mathrm{p}<0.001$. A direct correlation was determined between phosphorus and oxygen, magnesium and oxygen, chlorine and zinc, chlorine and sodium, zinc and sodium 

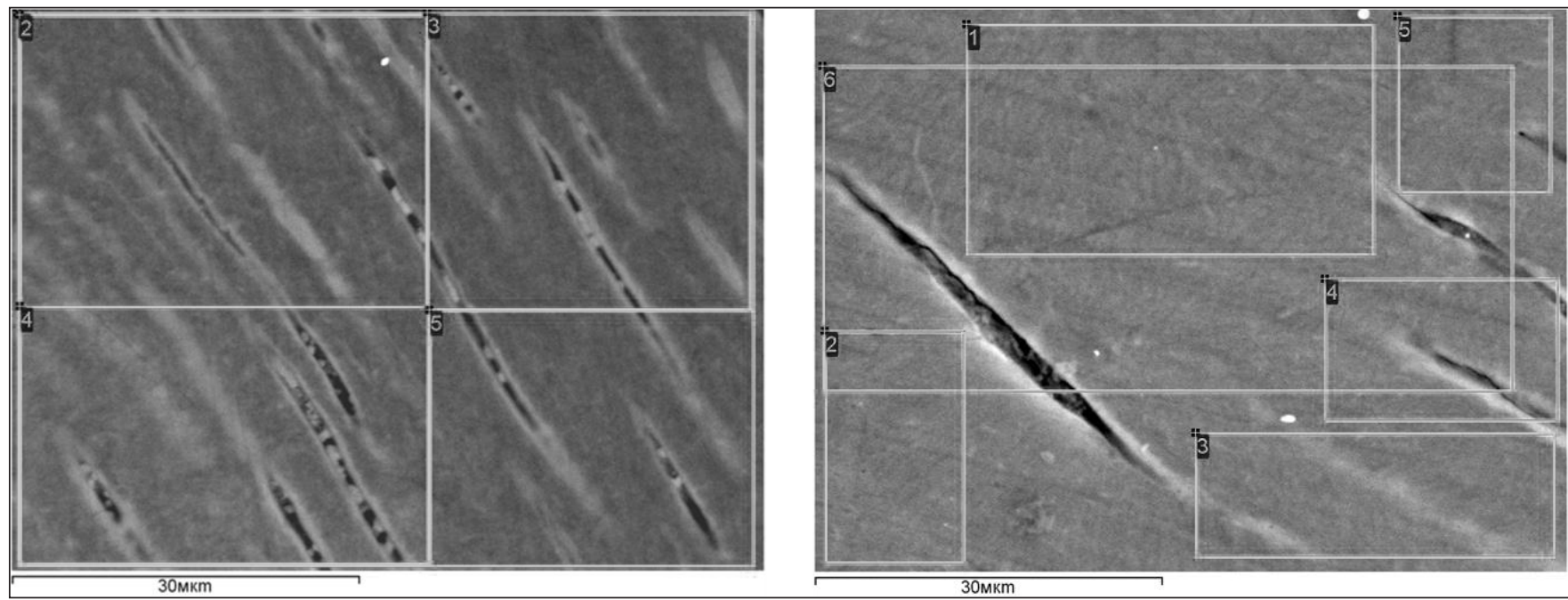

Fig. 1. Examined parts of dentine in the area of the incisal region (tubercle)
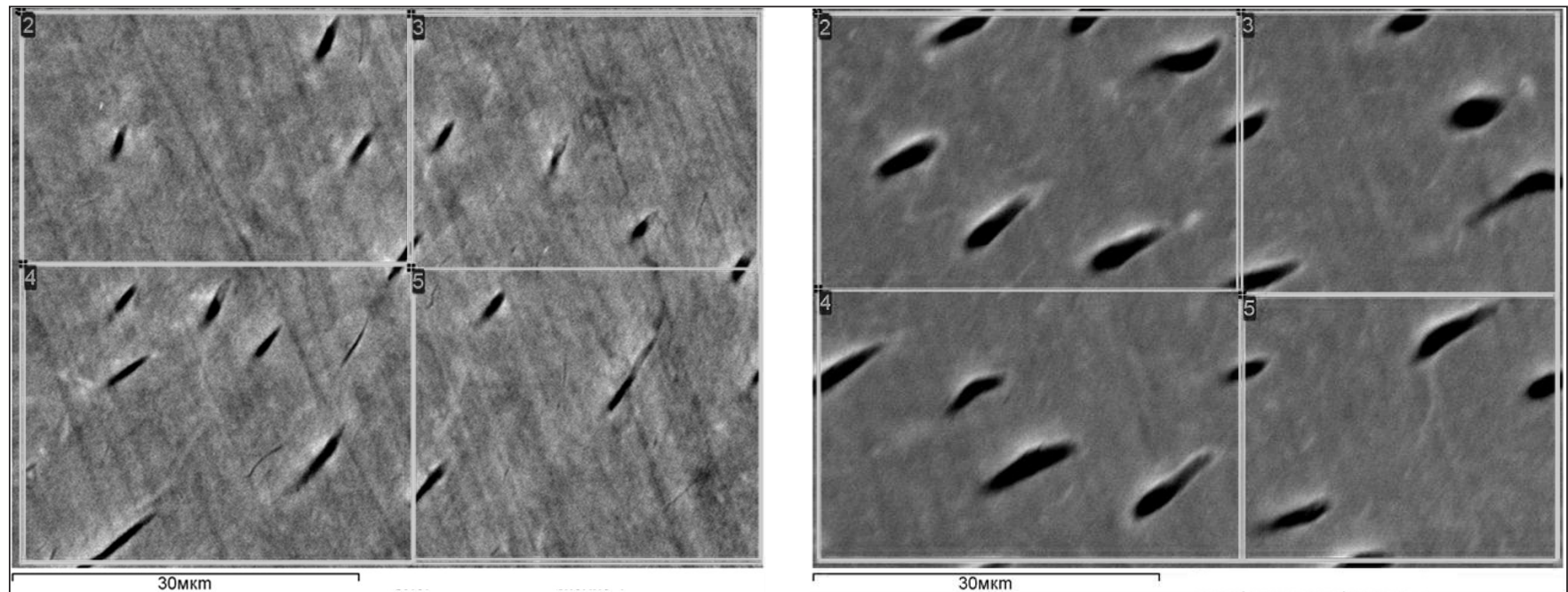

Fig. 2. Examined parts of dentin in the area of the equator
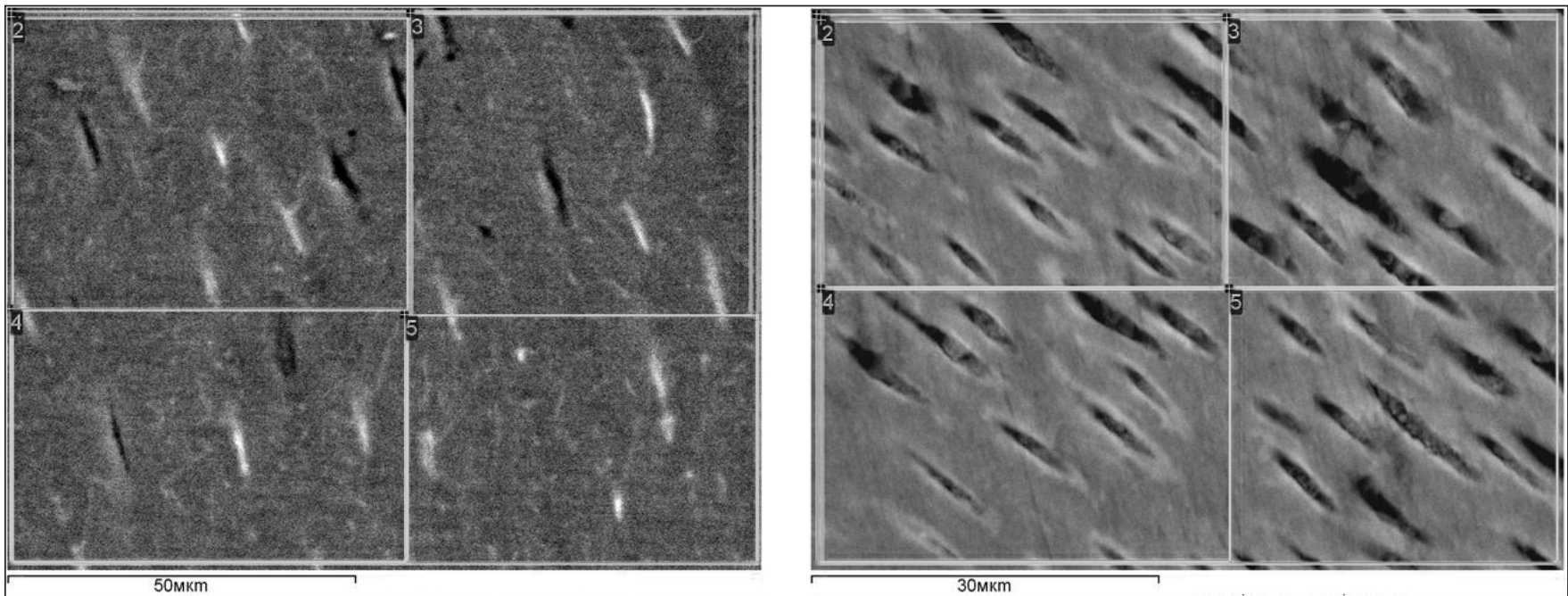

Fig. 3. Examined parts of dentin in the cervical area

in dentin of the teeth with NCCL, an indirect correlation between phosphorus and carbon, phosphorus and zinc, zinc and oxygen, $p<0.001$. Dentin of clinically intact teeth had a direct correlation between calcium and phosphorus content $(r=0.704), p=0.002$. The differences in the amount of carbon, sodium, chlorine, potassium and calcium were 
determined in the cervical region: the content of carbon and potassium was significantly higher $(26.59 \pm 2.67$ normal mass \% and $0.03 \pm 0.04$ normal mass $\%$, respectively) in the group of samples with NCCL, $\mathrm{p} \leq 0.05$ (table V). The content of sodium, chlorine, and calcium was higher in dentin of clinically intact teeth $(\mathrm{p}<0.001)$.

Examined parts of dentin in the cervical area are presented in figure 3 .

The results of the revealed correlation between the chemical elements of high strength in the cervical area are shown in Table VI.

A direct correlation between the content of phosphorus and calcium ( $r=0.905)$ has been revealed, an indirect correlation between oxygen and phosphorus $(r=-0.804)$, oxygen and calcium $(\mathrm{r}=-0.889)$ in the samples with NCCL, $p<0.001$. There was a direct correlation between the amount of oxygen and calcium in dentin of intact teeth $(\mathrm{r}=0.931)$, carbon and chlorine $(\mathrm{r}=0.812)$, phosphorus and calcium $(\mathrm{r}=0.810)$, chlorine and sodium $(\mathrm{r}=0.736)$; there was determined an indirect correlation between the content of carbon and oxygen ( $r=-0.893)$, carbon and phosphorus $(r=-0.875)$, sodium and calcium $(r=-0.757)$, sodium and oxygen $(\mathrm{r}=-0.846)$, chlorine and calcium $(\mathrm{r}=-0.803)$, calcium and carbon $(\mathrm{r}=-0.917), \mathrm{p} \leq 0.001$.

Thus, significant differences have been defined in the content of carbon, magnesium, phosphorus, chlorine, potassium, calcium in dentin chemical composition of clinically intact teeth; in the teeth with wedge-shaped defect carbon, sodium, magnesium, phosphorus and calcium depending on the examined area $(\mathrm{p} \leq 0.05)$. Using the comparative analysis of obtained findings distributed in the groups the differences have been identified: in the amount of oxygen, sodium, sulfur, chlorine and calcium in the area of the incisal region (tubercle); sodium, magnesium, phosphorus and zinc at the equator, carbon, sodium, chlorine, potassium and calcium $(\mathrm{p} \leq 0.05)$ in the cervical region. More mineral components were contained in the dentin of clinically intact samples with the exception of sulfur and oxygen - in the incisal region (tubercle), phosphorus and zinc - at the equator, carbon and potassium - in the cervical region $(\mathrm{p} \leq 0.05)$. It should be noted that the amount of sodium was significantly less in all areas of examined teeth with wedge-shaped defects (by 2.1 times - in the incisal region (tubercle), by 2.4 times - in the cervical area $(\mathrm{p} \leq 0.05)$.

A strong indirect correlation between the content of carbon and calcium was determined in the areas of the incisal region (tubercle) and the equator in both groups, and an indirect one between carbon and oxygen was defined in the equator region. Correlation was detected between calcium and oxygen in dentin of the equator and the cervical region: a direct correlation at the equator of all samples and in the cervical region of clinically intact samples, an indirect one in the cervical region of the samples with a wedge-shaped defect. A direct correlation of high strength was identified between phosphorus and calcium in the cervical area of the teeth of both study groups, in the area of the incisal region (tubercle) of teeth with NCCL, at the equator of intact teeth.

\section{DISCUSSION}

The heterogeneity of the distribution of chemical elements in the enamel and dentin of permanent teeth determined as a result of carried out studies $[14,15]$ is probably due to their role in ensuring hardness and resistance to external factors [13].

We have hypothesized that the level of chemical elements in dental hard tissues affects the onset and progression of NCCL. Demineralization of dentin that was observed in $69 \%$ of NCCL cases [10] contributes to their formation at an early stage, and occlusive stress contributes to the progression of pathology [6]. During demineralization the release of calcium precedes the release of phosphate from enamel, dentin and cement [16]. This fact explains significantly higher phosphorus content in the dentin of the equator of teeth with wedge-shaped defects compared with clinically intact ones. Obtained findings on the amount of magnesium and calcium in the dentin of the incisal region (tubercle), namely, a higher content of magnesium and a lower content of calcium at the level of $5 \%$ in the samples with wedge-shaped teeth agree with the results of the previous studies [17] in the teeth with occlusal wear facets that cause occlusal stress in the etiology of NCCL. A greater amount of magnesium in the dentin of teeth with wear facets can be a protective reaction to external influences [17]. Significant decrease in the amount of calcium in the incisal region (tubercle) and the cervical region in the dentin of teeth with wedge-shaped defects is explained by its role in the development of pathology of dental hard tissues $[12,13]$.

In the areas of the incisal region (tubercle) and equator of the samples of intact teeth and teeth with NCCL, in the cervical area of intact teeth there was determined an indirect correlation between carbon and calcium content in dentin which was also observed in the teeth with increased wear [12]. Significant differences in the amount of carbon were detected in the cervical region, $\mathrm{p}<0.001$. Other researchers identified a strong correlation between carbon and magnesium levels in dental dentin with a carious process [12]. According to our results such relationship has not been found in any of dentin areas of the samples of both groups that is probably due to the difference in the chemical composition depending on the state of hard tissues.

Revealed identical differences in dentin mineral composition of the incisal region (tubercle) and cervical region in the content of sodium, chlorine, and calcium indicate the possible role of these chemical elements in resisting occlusal stress. Obtained results agree with other researchers' findings [10] that the loss of dentin mineral components and occlusal injury may be etiological factors in the development and further progression of NCCL.

\section{CONCLUSIONS}

There has been confirmed the assumption of differences in dentin chemical composition of intact teeth and teeth with wedge-shaped defects in the incisal region (tubercle), equator, cervical area $(\mathrm{p} \leq 0.05)$. The heterogeneity of dentin 
chemical composition of the studied areas of clinically intact teeth and teeth with wedge-shaped defects is probably due to the loading of various sites and their morphological characteristics. The presence of correlation between dentin chemical elements of intact teeth and teeth with wedgeshaped defects confirms the possible role of macro- and microelements in the pathogenesis of NCCL $(\mathrm{p}<0.0001)$.

The perspective is in the studying of chemical elements in the content of which significant differences have been determined in the oral fluid and patients' blood serum with predisposing factors (including enamel microcracks) and appeared wedge-shaped defects and it will provide an individual approach to the prevention and treatment of NCCL.

\section{REFERENCES}

1. Faye B., Sarr M., Benoist F.L. et al. Prevalence and etiologic factors of non carious cervical lesions among prison's population in Dakar. J Dent Oral Care Med. 2015; 1(3):1-6. doi: 10.15744/2454-3276.1.303.

2. Zuza A., Racic M., Ivkovic N. et al. Prevalence of non-carious cervical lesions among the general population of the Republic of Srpska, Bosnia and Herzegovina. Int Dent J.2019; 69(4):281-288. doi: 10.1111/ idj.12462.

3. Yoshizaki K.T., Francisconi-Dos-Rios L.F., Sobral M.A. et al. Clinical features and factors associated with non-carious cervical lesions and dentin hypersensitivity. J Oral Rehabil. 2017; 44(2):112-118. doi: 10.1111/joor.12469.

4. Kolak V., Pešić D., Melih I. et al. Epidemiological investigation of noncarious cervical lesions and possible etiological factors. J Clin Exp Dent. 2018; 10(7):e648-656. doi: 10.4317/jced. 54860 http//dx.doi:.org / 10.4317 /jced. 54860.

5. Teixeira D.N.R., Zeola L.F., Machado A.C. et al. Relationship between noncarious cervical lesions, cervical dentin hypersensitivity, gingival recession, and associated risk factors: a cross-sectional study. J Dent. 2018; 76:93-97. doi: 10.1016/j.jdent.2018.06.017.

6. Nascimento M., Dilbone D., Pereira P. et al. Abfraction lesions: etiology, diagnosis, and treatment options. Clin Cosmet Investig Dent. 2016; 8:79-87. doi: 10.2147/CCIDE.S63465.

7. Femiano F., Femiano R., Femiano L. et al. Noncarious cervical lesions: correlation between abfraction and wear facets in permanent dentition. Open Journal of Stomatology. 2015; 5:152-157.

8. Igarashi Y., Yoshida S., Kanazawa E. The prevalence and morphological types of non-carious cervical lesions (NCCL) in a contemporary sample of people. Odontology. 2017; 105(4):443-452. doi: 10.1007/s10266017-0300-y.

9. Abdalla R.., Mitchell R.J., Ren Y.F. Non-carious cervical lesions imaged by focus variation microscopy. J Dent. 2017; 63:14-20. doi: 10.1016/j. jdent.2017.05.001.

10. Wada I., Shimada Y., Ikeda M. et al. Clinical assessment of non carious cervical lesion using swept-source optical coherence tomography. J Biophotonics. 2015; 8(10):846-854. doi: 10.1002/jbio.201400113.

11. Tkachenko I.M., Brailko N.N., Kovalenko V.V. et al. Morfolohicheskoe issledovanie emali i dentina zubov s karioznym protsessom i nekarioznymi porazheniiami. [Morphological study of enamel and dentin teeth with carious process and non-carous lesions]. Wiad. Lek. 2018; 70(5):1001-1005. (in Russian)
12. Tkachenko I. M., Kovalenko V.V. Doslidzhennia microelementnoho skladu emali i dentynu zubiv pry kariiesi ta pidvyshennii stertosti. [Research of microelement composition of enamel and dentine of teeth at caries and increased tooth erosion]. Visnyk problem biolohii i medytsyny. 2017; 2(140):248-252. (in Ukrainian)

13. Klimuszko E., Orywal K., Sierpinska T. et al. Evaluation of calcium and magnesium contents in tooth enamel without any pathological changes: in vitro preliminary study. Odontology. 2018;106(4):369-376. doi: 10.1007/s10266-018-0353-6.

14. Yarova S.P., Zabolotna I.I., Dubyna S.A. et al. Sravnitelnyy rentgenospektralnyy analiz khimicheskoho sostava dentina zubov $s$ klinovidnym defektom pri razlichnoy hlubine mikrotreshchin email. [Comparative X-ray analysis of chemical composition of dentin in teeth with a wedge-shaped defect at different depth of the enamel microcracks]. Science and Education a New Dimension. Natural and Technical Sciences. 2018;7(20): 172:41-44. (in Russian)

15. Yarova S.P., Zabolotna I.I. Khimichnyi sklad emali zubiv z klynopodibnym defektom. [The chemical composition of the teeth enamel with wedgeshaped defect]. Novini stomatologii. 2017; 1(90): 83-86. (in Ukrainian)

16. Abou Neel E.A., Aljabo A., Strange A., et al. Demineralizationremineralization dynamics in teeth and bone. Int J Nanomedicine. 2016; 11: 4743-4763. doi: $10.2147 /$ IJN.S107624.

17. Ey-Chmielewska H., Janiszewska-Olszowska J., Noceń I. et al. Effect of pathological tooth wear on the content of calcium, magnesium, zinc and phosphate in human dentin. Magnes Res. 2011; 24(1): 13-16. doi: 10.1684/mrh.2011.0270.

\section{ORCID and contributionship:}

Svitlana P. Yarova: 0000-0002-7830-4579 A,E,F

Iryna I. Zabolotna: 0000-0002-3284-0392 B,D,E

Olena S. Genzytska: 0000-0002-4694-8679 C

Andrii A. Komlev: 0000-0002-5355-6331 ${ }^{B}$

\section{Conflict of interest:}

The Authors declare no conflict of interest.

\section{CORRESPONDING AUTHOR Olena S. Genzytska \\ Donetsk National Medical University \\ 27 Privokzalna st., 84404 Lyman, Ukraine \\ tel: +380954192232 \\ e-mail: blacky3000@mail.ru}

Received: 25.06 .2020

Accepted: 02.06 .2021
A - Work concept and design, B - Data collection and analysis, C - Responsibility for statistical analysis, D-Writing the article, $\mathbf{E}$-Critical review, $\mathbf{F}-$ Final approval of the article 